\title{
Publication and Study of a Rare Terracotta Piece from Naucratis Preserved in the Egyptian Museum in Cairo
}

\author{
Mustafa Muhammad Qandil Zaied* \\ Professor of History of Ancient civilization, King Khalid University, Faculty of Humanities, Professor of \\ classical Archaeology, Ain Shams University, Faculty of Arts, Egypt
}

*Corresponding Author: Mustafa Muhammad Qandil Zaied, Professor of History of Ancient civilization, King Khalid University, Faculty of Humanities, Professor of classical Archaeology, Ain Shams University, Faculty of Arts, Egypt

\begin{abstract}
This paper aims to shed the light on a rare terracotta figurine at Gallery No. 39 in the Egyptian Museum in Cairo. The artistic features of the figurine clearly suggest that it goes back to the Ptolemaic and Roman eras. The most eye-catching feature of this terracotta is that it has never been studied or published before. Furthermore, this piece was selected carefully by the researcher to represent irrigation which referring to different aspects of daily life at that time. The researcher selected a terracotta of a male depicted by the artist while practicing their professions or carrying tools that refer to the nature of the profession they practice. In fact, this piece was selected because depicting males in the terracotta art was very rare compared to the figurines of women that represented a remarkably common feature of the terracotta art during the Greek and Roman eras, most important of which - of course - are Tanagra figurines.
\end{abstract}

Keywords: Terracotta, figurines, women, Male, Egyptian Museum.

\section{INTRODUCTION}

The term terracotta as used in the field of classical archaeology refers to a type of figurines made of raw clay and distinctive to the Hellenistic and Roman eras. In fact, this art is rich in innovation whether in hand-made figurines or those molded. It is also rich regarding the variety of themes it represents. It goes without saying that this art represents the lowest class in society, while bronze and marble sculptures represent the higher classes of society in view of the high costs and high degree of skills required for modeling and molding compared to raw clay sculpture. However, archaeologically speaking, the terracotta art is very important and even superior to other arts as it provides a diversity of themes that are unrepresented in other arts. In addition, depicting professions and occupations is closely related to the terracotta art, hence it is more properly described as the street art. Besides, males were specifically selected by this study because of their physical nature that requires them to make a living through such professions and occupations. As a matter of fact, males are more mobile and active into streets than females who used to practice their domestic housework in their houses, except in rare circumstances where they would work outside.

Furthermore, the Ptolemaic and Roman terracotta figurines from Naucratis comprise a large and varied group of artefacts, including figures, figure vases, model and coffin fittings spanning the period from the end of the fourth century $\mathrm{BC}$ through to the seventh century $\mathrm{AD}$, reflecting the continued significance of the settlement into the Roman and Byzantine periods. ${ }^{1}$ This took place after the King Psamtik I (569-566 BC) dedicated this city to all Greek citizens living in Egypt. Since then, Naucratis became one of four cities, along with Alexandria and Ptolemais and Antinopolis, in which the Greeks used to settle during the Ptolemaic reign. During this era, the Romans considered the inhabitants of these cities as Cives peregrine or astoi, whose previous privileges and high status must be preserved. ${ }^{2}$ Furthermore, formal intermarriage between the citizens of these cities and the locals during the Roman era was prohibited with the purpose of protecting their racial purity. ${ }^{3}$

\footnotetext{
${ }^{1}$ Thomas 2015, 2.

${ }^{2}$ Barans 1978 ,7; Capponi 2005, 66-69; Vandorpe 2012, 262-263.

${ }^{3}$ Nushy 1966, 2-5; Al Ibiary 2004, 121-124. 


\section{DISCUSSION}

The terracotta figurine published in this paper was found in Kom-Gieif, ancient Naucratis ${ }^{4}$. The figurine is in the Gallery no.39 of Cairo museum (Reg. No. 26752) it has a maximum height of 5.5 $\mathrm{cm}$; Width: $10 \mathrm{~cm}$ and length: $5 \mathrm{~cm}$. The figurine is in an excellent case of preservation (pl. 1. A- C). An attempt shall be made to define the figurine's history based on its artistic features or models, through comparing them to their peers whose chronology is known. The terracotta figurine depicts a young man sitting in an irregular posture whilst holding a water skin (pl. No.: 1A). He is leaning to the ground on his knees, trunk and elbows bending over the water skin. Meanwhile, he is stretching his head forward up; and his legs backwards to rely on the water skin that he is leaning on, which is the base of the figurine itself (pl. 1. B) whereas holding the water skin and projecting its ring mouth, more likely to a fountain, or a waterfall with a full concentrating looking up face features, trying to fill it with water. The young man is depicted naked except from a band of a lion skin. The lion skin is recognized by the lion's paws tied around his neck and hanging down his back. He is leaning on a water band. At the end of the band, there are some scattered hairs on the water skin (pl. 1.C), which indicates that the band is made of a goat's skin. The suggestion that the water skin is made of a goat's skin is affirmed by two indications. First, the water skin takes a streamlined wavy shape as appears under the young man - the irrigator. Second, the mouth of the water skin is also wavy-shaped which is signified by his grip on it. These two factors indicate that the water skin is made of a flexible raw material, which is more likely a goat's skin. The band and the lion skin together form a semi-circular shape designed perhaps to make the figurine easy to grasp through this cavity.

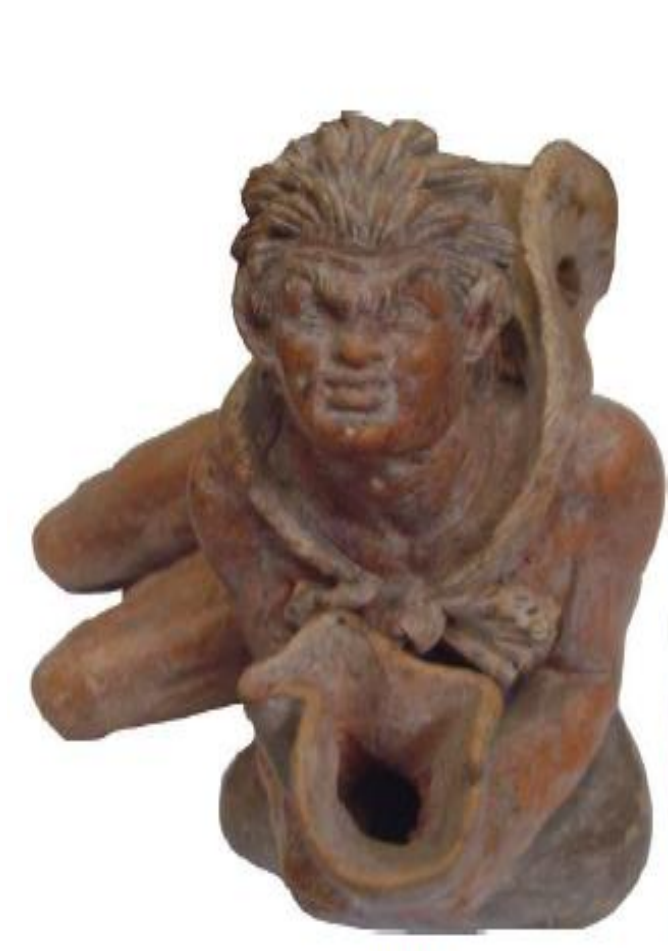

Pl. $1 \mathrm{~A}$

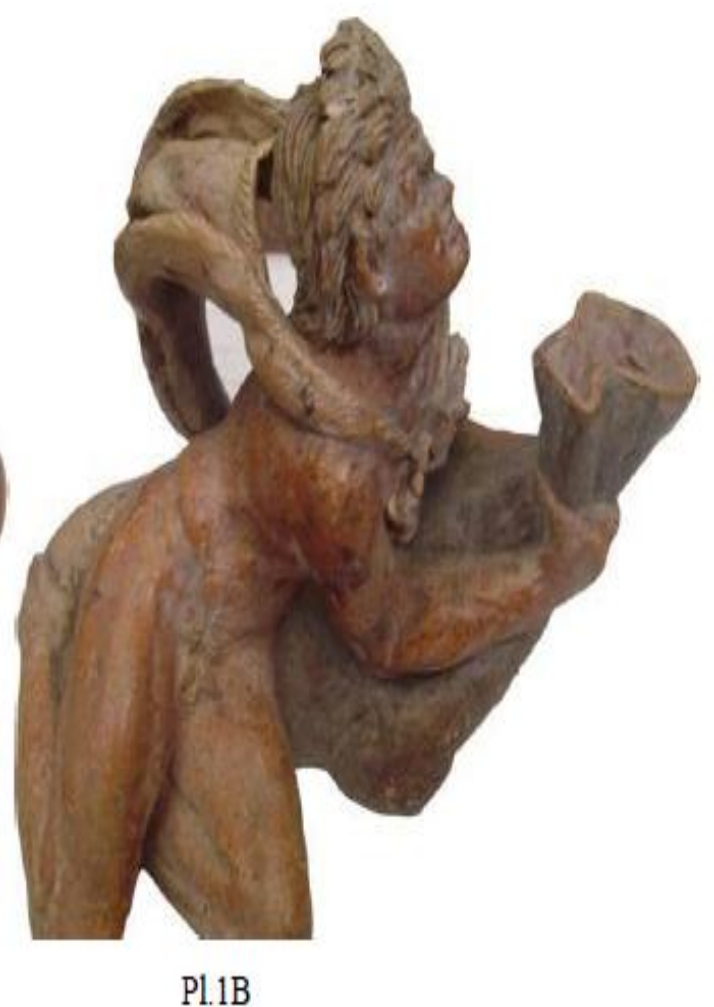

Pl.1B

\footnotetext{
${ }^{4}$ According to the registers in Cairo museum, the terracotta figurine comes from Kom Gieif (ancient Naucratis

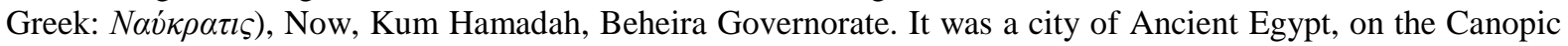
branch of the Nile River, $45 \mathrm{mi}(72 \mathrm{~km}) \mathrm{SE}$ of the open sea and the later capital of Ptolemaic Egypt, Alexandria. It was first settled in by a group of Miletus immigrants in the seventh century BC. It continued to play its cultural role till the decline era caused by the shifting of the Nile by the end of Roman era in Egypt. Naucratis was a Greek colony established at the orders of King Psamtik I. In fact, this king enlisted the aid of Greek soldiers in the Egyptian army. Objected by local citizens for doing so, he decided to make them settle in an area near his capital in western Delta to keep them away from clash with locals while not far from him. See: Fawzy Mikkawy, Tarikh Al-`Alam Al-Ighriqi wa Hadaratuh "History and Civilization of the Greek World", (Casablanca: 1981, 108-109).
} 


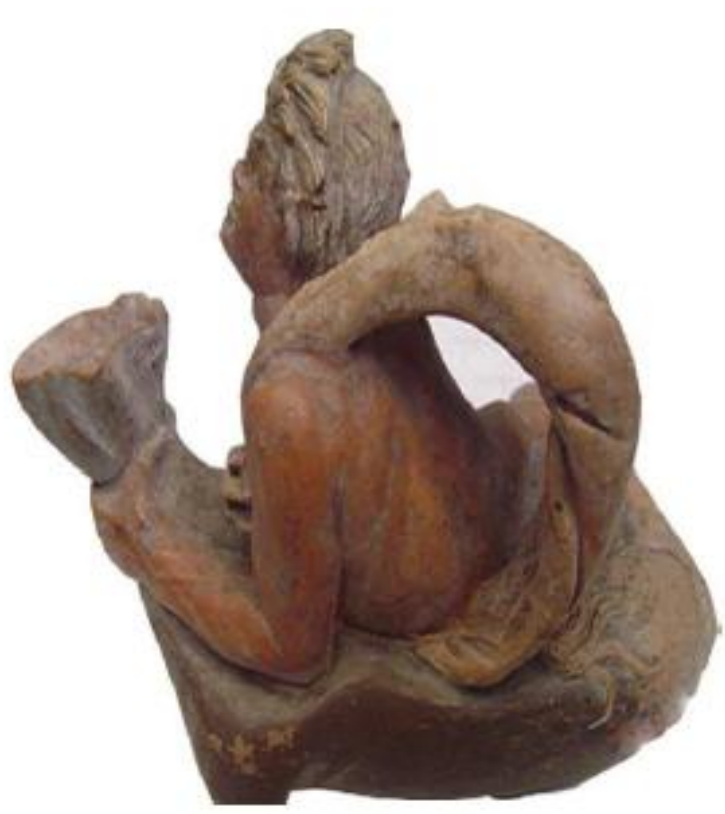

P1.1C

The young man has a plump face and furrowed forehead, the eyebrows are thick and connected together, raised in the outer corners and the inner corners are drawn together to midline, and forming two deep horizontal lines in the forehead ${ }^{5}$; The eyes incised carefully with circular upper and lower lids, and round irises and pupils; The nose is small; The mouth is slightly open, with fleshy parted lips; and a pointed chin; The earlobes are well incised and little in size. As for the hair style, it is treated entirely in the round, styled in protruding thick hair locks patterned in three rows, notable that the locks get longer and looser as we reach the back of the neck, which is fully covered by hair; the neck is raised to look up straightly. The skillfully incised features of the whole face are noteworthy, which is quite rare for a terracotta figurine! And if we tried to detect the emotion expression on the face features of the figurine, we can apply Ekman's FACS method ${ }^{6}$ dividing the face into three regions: (1) the furrowed wrinkled forehead and raised drawn together in the midline brows; (2) the eyes with carefully incised circular eyelids, with lowered upper lid corners and a sharp concentrating look up; (3) the mouth with slightly parted lips, and raised upper lip corners. These facial indications affirm a strict, serious concentrating expression on the figurine's face ${ }^{7}$. Interestingly, the eyes are so

\footnotetext{
${ }^{5}$ When the constriction of both the corrugatormuscles 'responsible for drawing the eye brows to midline', and the frontalismuscle 'responsible for elevating eyebrows', to raise and draw the eyebrows together in the same time, it causes the formation of deep horizontal lines in the forehead 'temporal wrinkles' (Van de Graff et al. 1997, p.191,fig.8.18.) Which is a quite unusual accuracy in forming the details of face features of a terracotta figurine, it is known of Alexandria school of sculpture to give such attention to the human physiognomy of face and body, in its products of different sculptures and at all scales, but this piece is quite like no other of the terracotta products of Alexandria school of art (Török 1995.).

${ }^{6}$ Facial Action Coding System, or FACS - that regards the muscles below the surface of an expression, encoding according to the precise movements of these muscles. In fact, the FACS can reputedly identify as many as tenthousand expressions. A system that permits an analyst to specify an expression far more precisely and objectively than was previously possible, an initial discovery by Paul Ekman, which is considered a reliable method to apply on classical art to analyze face and body expressions and try to detect emotions out of it. The method is recorded in his book Unmasking the Face, and updated in his second book, Emotions Revealed. Inasmuch as this is the method of Unmasking the Face, it is the method of Ekman and Friesen; but for brevity's sake I will speak simply of "Ekman's method," recognizing additionally that he has been the major contributor in this book and since. Ekman's method goes this way: he divides the face into three regions: (1) the forehead and brow; (2) the eyes (especially the eyelids); (3) the lower face (especially the mouth, but sometimes also the nose). For each region there are many possible movements. By focusing on the particular movements in each of these three regions, and seeing how they are combined, a facial analyst can diagnose with great precision and objectivity the emotion conveyed by a face. According to Ekman, there is nearly always at least one movement in each region that is characteristic of each basic emotion. The basic emotions include at least the following six: surprise, fear, disgust, anger, happiness, and sadness.

${ }^{7}$ Ekman, Friesen 2003, 98.
} 

Cairo

skillfully projected forward to be consistent with his nick since he is raising it to look above in such a manner that resembles the look of Alexander the Great's as depicted by Lysippos. ${ }^{8}$ The iris and the pupil of the eye are realistically and skillfully depicted. As for the man's hair, it is depicted long, thick and loose. The artist portrayed it as having curls in rows. The hair is hanging back loose covering the whole back of the neck. It is noteworthy that the thickness of the hair shortens the forehead on which some wrinkles are portrayed to represent the irrigator's seriousness and strict look. Notably, the facial features of this young man resemble those of a head of the Gaul young man (pl. 1. A- B). That was excavated in Giza and is preserved in the Egyptian Museum, which date by the end of $3^{\text {rd }}$ century B.C, ${ }^{9}$ which characterized the art of the city of Pergamon during the Hellenistic and Roman eras. ${ }^{10}$

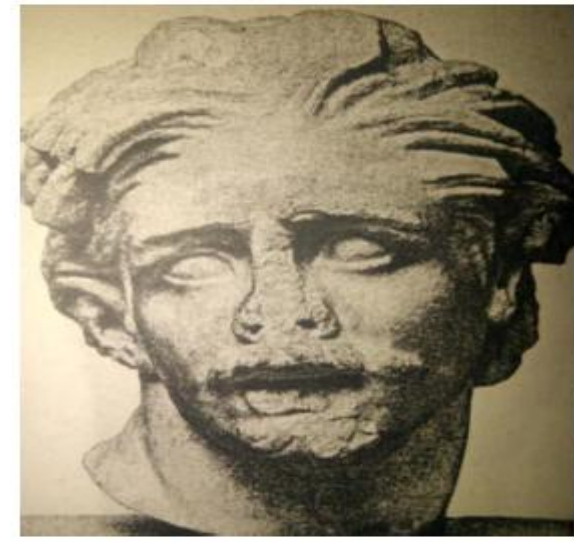

Fig.1a

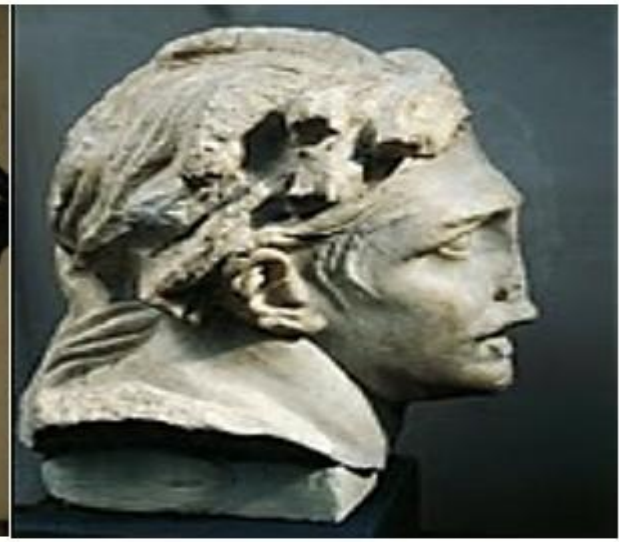

Fig. 1b

The raw material of which this figurine is made is the Nile silt which takes the dark brown or reddishbrown color after it is burnt. ${ }^{11}$ When comparing the color of its fired Nile silt to that of the terracotta collection preserved in the British Museum whose source is Naucratis, we will find out that the latter's color is dark brown. However, some of them are glazed while the others are not. ${ }^{12}$ Moreover, there are many similar terracotta pieces that are made of the same raw material preserved in the Greek and Roman Museum ${ }^{13}$, and in the Ashmolean Museum (fig.2a, b) ${ }^{14}$.

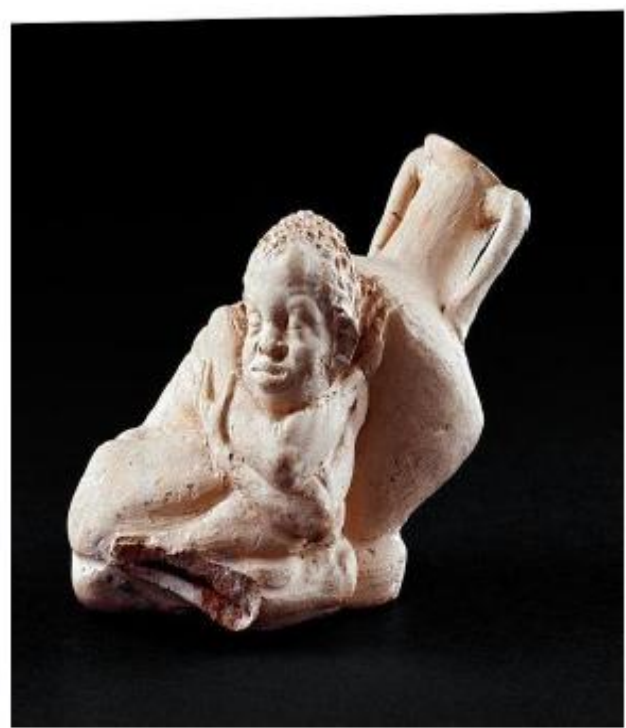

Fig.2a

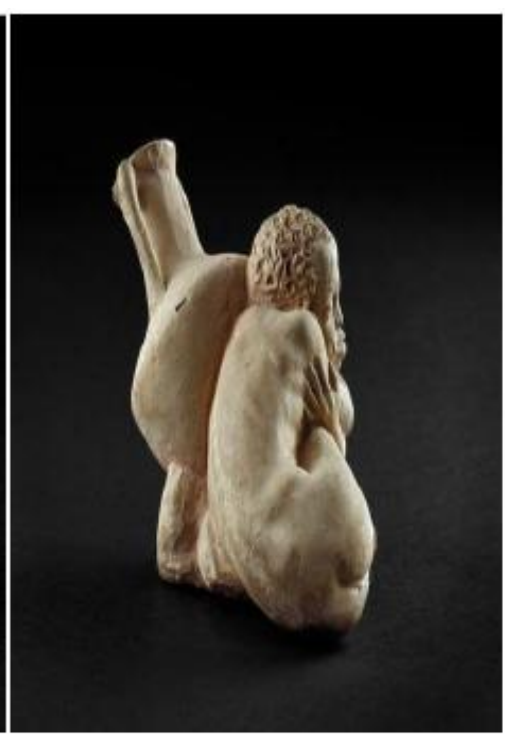

Fig. $2 \mathrm{~b}$

\footnotetext{
${ }^{8}$ Pollitt1986, 47-58. Adriani 1948, 32; Bieber1956, fig 273; Bieber1956, fig273; Grimm 1971, fig 2-5.

${ }^{10}$ Al-Fakharany 1963, 116.

${ }^{11}$ Prinz 1908, 84-86.

${ }^{12}$ Higgins 1542 .404-407, nos. -50 .

${ }^{13}$ A large head negro figurine (Bereccia 1930, 5-8; Dunand 1990, 15-19.

${ }^{14}$ Hogarth 1903,134.
}

${ }^{9}$ INV.CG 27475. Maspero, 1908, fig. 67; Mariette1872, 39; Reinach 1889, 26; Edgar 1903, Pl.X, fig.20. ; 
Concerning the technique, the figurine was undoubtedly hand-made which represents a unique and a rare condition. The terracotta figure is fired in an oxidizing atmosphere, at a low oven temperature that gave the figurine its coarse surface texture. The surface is marked by some cracks, and vesicles left by some straw inclusions, then it was coated in a gypsum-based, a white wash that covered the rough cracked surfaces left in the fabric that obscured the fine detail of the figurine, before being painted brightly with red pigment ${ }^{15}$ By the same token, all the parts of the figurine are skillfully shaped. In fact, the artist excellently shaped the figurine and paid much attention to all the physiognomic details of the irrigator's body and managed to manifest the seriousness on his face through expressive features. Moreover, the technique known as "Sfumato" ${ }^{16}$ clearly appears in the plump, clear of bones face. The artist was also skillful and professionally realistic in shaping the muscles of the body; however, the most expressive part of the figurine is the head area, this is applicable to the countenance, hair shape, fleshy neck, and the body's curvature and flexibility. In fact, the execution of this distinguished posture was perfectly streamlined. This is in addition to the wavy effect added to the water skin. All these artistic features are in line with the style and artistic features of Praxiteles ${ }^{17}$, whose style influenced the Alexandrian school of art during the Greek and Roman eras. In fact, it is likely that the artist who incised this figurine is an adherent of Alexandria school of art.

Concerning the dating of the figurine, we have a clear archaeological evidence for at least two terracotta workshops operating in north-east Naukratis from the end of the 4th or early 3rd century $\mathrm{BC}$, until at least the 2 nd century $\mathrm{BC}^{18}$. The two workshops were situated within an industrial area in the north-eastern part of the town, just to the east of the Hellenion and alongside other workshops ${ }^{19}$. Numerous other local terracotta 'industries' have been identified on the basis of figures and moulds in other styles, using different techniques and technologies, but cannot be specifically located. Production continued throughout the 3 rd to 2 nd centuries $\mathrm{BC}^{20}$. when other artefact groups, such as mould-made pottery, portable stoves and lamps, may also have been made there ${ }^{21}$.Roman figures could have been produced in as yet unexplored parts of the site, as no evidence of their manufacture has so far been discovered at Naukratis, although lamps were certainly made in Naukratis at this time $^{22}$. Meanwhile Locally produced figurines of the Ptolemaic and Roman periods were made of a dark red-brown to orange highly micaceous and organic Nile silt, often with quartz and white inclusions, low firedand light in weight ${ }^{23}$. The Roman technique and technology were the same, though cruder, and the figures were not always painted, but red-slipped instead. Despite the introduction of the thick gypsum coating that was often applied, the highly stylized form and exaggerated features of Roman figures may have remained more visible than would have been the case in examples with a more subtle, naturalistic style ${ }^{24}$. Ptolemaic figurines from Naucratis can be broadly divided into 10 categories as follows: Egyptian deities, Greek deities and mythological characters (including satyrs and maenads), actors and the theatre, 'Tanagra style' figures, male and female cult followers and priests, pregnant female 'orans' figures, votive models of animals and objects, figure vessels and ampullae, and finally coffin fittings with just a few miscellaneous pieces not fitting into these groups. Roman figurines largely follow the pattern set by figures of the Ptolemaic period, though with a more restricted subject range and are fewer in number, as is also the case elsewhere in Upper and Lower Egypt, Roman period figures at Naukratis are quite different to those of the Ptolemaic period, Differences include a change in style, quality, subject and quantity

\footnotetext{
${ }^{15}$ For further about Naucratis terracotta industry techniques (Burn and Higgins 2001, 313-15; Qadus 2005, 252; Bailey 2006, 264)

${ }^{16}$ Pedley 2002, 308.

${ }^{17}$ Boardman 1984, 69-71; Pollitt 1986,161; Pedley 2002, 307-309; Stafford 2004, 66.

${ }_{18}$ As An established local terracotta industry represented by kilns, moulds and terracotta figurine wasters was found in two separate, but adjacent locations (Petrie 1886, 45, 'Site 95'; Edgar 1905, 121, 'Site 38').

${ }^{19}$ Petrie 1886, 39, pl. 41

${ }^{20}$ Bailey 2008, 5.

${ }^{21}$ The local Nile silt fabric was probably sourced and processed in a similar fashion for all these productions during the Ptolemaic period. Workshops for both figurine and relief-ware pottery production are attested in Athens and Alexandria from the late 4th century BC onwards and can be linked with metal working (BarrSharrar 1990, 32-5, fig. 25).

22 Thomas 2015, p.3.

${ }^{23}$ Boutantin 2014, 6-9; Thomas 2011a, 79.

${ }^{24}$ Thomas 2015, p.3
} 

Cairo

produced and consumed at Naukratis ${ }^{25}$. Over the course of the Roman period, a cruder stylized figuretype was being made across Egypt, featuring the changing hairstyle fashions of the time, with its own distinct style from the late 1st or 2nd century AD. These figures were mass produced, without much of the fine detail found on some of the Hellenistic type ${ }^{26}$. Good parallels are known from across Egypt, including Karanis in the Fayum ${ }^{27}$, Herakleopolis Magna ${ }^{28}$, and Middle Egypt. ${ }^{29}$

When comparing this figurine to most of the 134 Ptolemaic and Roman figure fragments known to come from the town at Naukratis, probably come from the domestic rubbish deposits, where they were discarded at the end of their useful lives ${ }^{30}$, and specially with the Ashmolean museum's head of Athena ${ }^{31}$ which is the closest to our figurine on the basis of the fired nile silt color and pigment, along with the definitive rounded and circumscribed shape incision of the pupils and irises of the irrigator's, I suggest that it can be dated to probably 1 st century BC to 1 st century AD. Which could be affirmed by the irrigator's face features and body structure's resemblence with the anthropological features of Gauls $^{32}$, as described by Diodorus scilius ${ }^{33}$, especially their coarse hair. The figurine's features are very similar to the Gaul's head from Cairo museum which suggested date is the late second century B.C ${ }^{34}$.

The model of an irrigator in the Egyptian Museum (pl. 1. A- C) can be compared to a white marble figurine preserved in the Roman Greek Museum in Alexandria (fig.3). This 41-cm-high figurine is purchased from Lower Egypt. ${ }^{35}$ The figurine is the lower half of a farmer - or may be irrigator? without a head, which dates to the late Hellenistic Period ${ }^{36}$. The resemblance is that this person wears a transparent exomis leaving a good part of his chest uncovered. He bears a basket on his back tying it around his chest and shoulders with a double robe to tighten it up, which, may refer to the heavy weight of the basket.

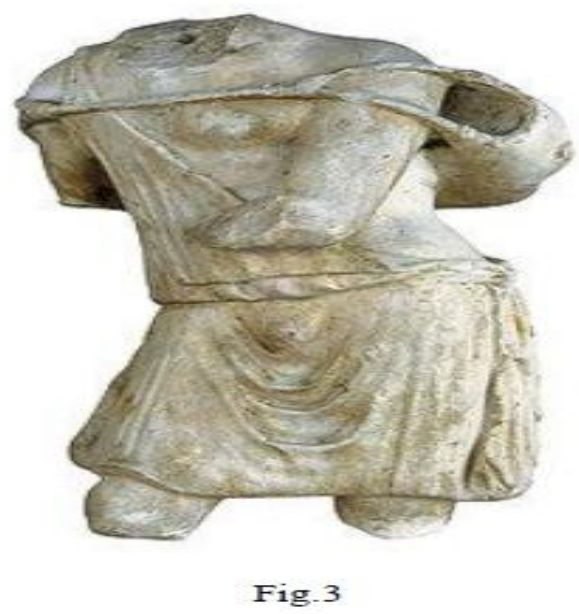

${ }^{25}$ Bailey 2006, 261-4; 2008, 5, 43-5, 111; Thomas 2011a, 79-84; Thomas and Nicholson 2013, 201. ;Thomas 2015, p.6-7

${ }^{26}$ Barrett 2011, 89-116.

${ }^{27}$ Allen 1985 , nos 82 and 83.

${ }^{28}$ Török 1995, nos 174-7.

${ }^{29}$ Besques 1992, no. E 392.

${ }^{30}$ Thomas 2011a, 79; Thomas and Nicholson 2013, 201; Bailey 2006, 261-4.

${ }^{31}$ Head from terracotta figure of Athena, probably 1st century BC to 1 st century AD, found with Ptolemaic pottery and figures dated c. 330-250 BC in well no. 36 (= well B). Ashmolean Museum(Thomas 2015, fig 53)

${ }^{32}$ Caucasian Northern group, large in size, tall and with large musceles, with thick corrugated red hair in long, coarse, locks.

${ }^{33}$ Diodorus records that the Gauls used lime on their hair to take the tough form and the locks seem to be coarse, lumpy and pointed, increasing the size of their heads and giving them a terrifying appearance and a larger body (Diod. 5. 28.1.)

${ }^{34}$ it was excavated in Giza and is preserved in the Egyptian Museum, which date by the end of $2^{\text {nd }}$ century BC, INV.CG 27475. (Mariette, 1872, p.39. ; Reinach, 1889, p.26. ; Edgar, 1903, Pl.X, fig.20. ; Adriani, 1948, p.32.; Bieber, 1956, fig. 273; Bieber, 1956, fig. 273; Grimm, 1971, fig. 2-5).

${ }^{35}$ Registry No: 23, Gallery 16; First published by Bonacasa 1960, 170 ff.; Adriani 1972, 141, no. 3, tav. 25, 3; Hassan 2003, 132..; Haggag 2019, 93, fig.5a.b.

${ }^{36}$ Bonacasa , 1960,170 ff.; Adriani , 1972: 141, no. 3, tav. 25, 3; Ridgeway 2000, 59; 73, pl. 25; Haggag 2019, 93, fig.5a, b. 

Cairo

A comparative study of the two models reveals that all the parts of the two figurines are skillfully hewn and shaped to depict a particular moment. In the model of the Greek Roman Museum, the artist depicts the farmer while performing the duties of his job. To illustrate, he is carrying a basket on his back while walking and bending a little forward burdened by the heavy size of the basket. As for the model of the Egyptian Museum, the artist depicted it in a state of relaxation perhaps after finishing his work. In spite of this diversity, both models indicate a peerless advanced stage of art development. Significantly, the two examples referred to above were excavated in Delta.

\section{CONCLUSION}

I hope I have shown above how special this figurine is regarding to the skillfulness of its sculptor. Hence, it is not surprising that this figurine was found in city of Naucratis, a city of great importance at all times. As Naucratis started as a settlement in the western Delta many centuries before Alexander the Great's invasion of Egypt, it continued to witness an economic boom up until the Roman era when the city lost some of its glory. Thus, there is no doubt that discovering such a good quality and skillfully-made piece of art belonging to the second century AD indicates that the city was witnessing a renaissance on both the economic and cultural levels. Moreover, this indicates that it was undoubtedly inhabited during that ear as deduced from the existence of an irrigator who used to rove around the city from one end to the other to practice his profession. It is also noteworthy that depicting the irrigator as naked showing a perfect body indicates the dominant Greek feature of sculpture. This indicates that Greeks represented the majority of the population of the city during the Roman era. This hypothesis is attested by literature on the subject and Greek papyri discovered in Egypt, which in total attest that Naucratis became a free Greek city "Пo $1 \varsigma^{\prime}$ " (ca. 569- 566 BC).

This figurine and the comparative examples I used indicates that artists during the Roman era were keen to reflect the activities of all the classes of the Egyptian society, especially lower classes, which is a unique characteristic of the terracotta art. It is noteworthy that the artist in the two examples was keen to feature the rippling muscles and well-built skeleton. It seems that it was a prerequisite for an irrigator to be physically strong in order to bear the difficulties of this burdensome profession. Study also reveals that the irrigation profession was widespread in small towns and gained reputation outside the capital city.

Moreover, the similarity of the facial features between this figurine and the head of the Gaul at the Egyptian museum, makes it more likely that this young man was a Gaul as well. He probably migrated to Egypt and lived in Naucratis with high-class population to practice this profession. It seems that this figurine is the product of Alexandria school of art, since the glaze, which is the luminous layer that was used to glaze instruments and figurines that were used to decorate houses or were kept with the dead in their graves. In fact, this school had the most significant impact on the development of the glass industry. Moreover, Alexandria was the main, if not the only, producer of this industry and was competed only by Syria.

Through the above presentation of this terracotta, which is distinguished from other arts by depicting such professions and reflecting the activities in the Egyptian street at Ptolemaic and Roman eras. The profession of irrigation as represented by this figurine, was a male profession and not suitable for women for it required a physical strength.

Furthermore, the settlement of Naucratis boomed during the Roman era and was distinctive as far as culture and art are concerned. However, some other figurines were shaped manually, in which case special attention was paid to all the details of the figurine.

\section{REFERENCES}

[1] Adriani, A., 1948. Alessandrina documenti recerche d'arte alessandrina II, Rome.

[2] Al-Fakharany,F.,1963. Al-Iskandriyyah wa Al-Fann fi Al-`Asrayn Al-Yunany wa Al-Romany, min AlIskandriyyah mindhu Aqdam Al-'Usur "Alexandria and Art in the Greek and Roman eras, Alexandria Since the Earliest Ages", Alexandria.

[3] Al-Ibiary, H.2004, Egyptian Social and Economic History under the Roman Rule", Cairo.

[4] Allen, M.L., 1985. The Terracotta Figurines from Karanis: A Study of Technique, Style and Chronology in Fayoumic Coroplastics, 2 vol., UMI, Ann Arbor. 
[5] Bailey, D. M. 2006. Terracotta and plaster figurines, sealings and a stone group. In Mons Claudianus 3, Ceramic vessels and related objects, 261-88, V. Maxfield and D. P. S. Peacock (eds). Cairo.

[6] Bailey, D.M. 2008. Catalogue of terracottas in the British Museum. Vol. IV: Ptolemaic and Roman terracottas from Egypt. London.

[7] Barrett, C. E. 2011. Egyptianizing figurines from Delos: A study in Hellenistic religion. Leiden.

[8] Barr-Sharrar, B. 1990.'coroplast, Potter, And Metalsmith' in J.P. Uhlenbrock et al. The Coroplast's Art: Greek terracottas of the Hellenistic world, New Rochelle, pp.31-36.

[9] Barans, J. 1978. Egyptians and Greeks, pap., Brux.14.

[10] Besques, S. 1992. Catalogue raisonne des figurines et reliefs en terre-cuite grecs, etrusques et romains. Vol. III. Paris.

[11] Bieber, M., 1961. The sculpture of helllenistic age, Columbia university press, USA.

[12] Boardman, J.1984. Greek Sculpture, The Classical Period, London.

[13] Bonacasa, N.1960. "Segnalazioni Alessandrine II. Sculture minori del Museo Greco Romano di Alessandria”, ArchClass. XII, 170-188.

[14] Boutantin, C. 2014. 'Terres cuites et culte domestique. Bestiaire de l'Égypte gréco-romaine'. In: Religions in the Graeco-World 179. Leyde and Boston.

[15] Burn, L., Higgins, R., 2001. Catalogue of Greek Terracottas in the British Museum: Volume III, London.

[16] Breccia, E. 1930. Terre Cotte Figurate Greche e Greco - Egizie del Museo di alessandria , in Monuments d'Egypte Greco - Romaine, II, Bergamo .

[17] Capponi, L., 2005. Augustan Egypt:e Creation of a Roman Province. New York: Routledge.

[18] Diodorus Siculus, Library, with an English Translation by C. H. Oldfather, London, William Heinemann, Ltd. (1989).

[19] Dunand, J. 1990. Catalogue des terres cuites Greco Romain d'Egypte, Paris.

[20] Edgar, C., 1903. 'Greek Sculpture', Catalogue general des antiquities egyptiennes du musee du Caire, Le Caire.

[21] Grimm, G., 1998, 'Alexandria', in Mainz am Rhein, Die konigsstadt der hellenistischen welt, Berlin.

[22] Haggag, M.2019. 'Cosmopolitan Trends in the Arts of Ptolemaic Alexandria, Edições Afrontamento'; in: CITCEM - Centro de Investigação Transdisciplinar «Cultura, Espaço e Memória»; Centro de Estudos Clássicos e Humanísticos; Alexandria University; Imprensa da Universidade de Coimbra.

[23] Hassan,F . 2003. Alexandria: The Greek Roman Museum", Supreme Council for Antiquities.

[24] Higgins, R.1969. Terracottas of Greek and Roman Antiquities in The British Museum, London, Vol. I.

[25] Hogarth, D.G., Lorimer,H.L , and Edgar,C.C. 1905. Naukratis, 1903. JHS 25 , 105-136.

[26] Kleiner, D.1992. Roman Sculpture, London.

[27] Lane, A. 1971. Greek Pottery, London.

[28] Mariette, E, 1872. Album Du Musee De Polaq, Le Caire.

[29] Maspero, G.1908. Guide to the Cairo Museum, (T. by A. Quibell), Cairo.

[30] Mikkawy,F.1981. History and Civilization of the Greek World", Casablanca.

[31] Nushy,I. 1966. Egyptian history during the Ptolemaic Era", Al-Anglo Massriyyah, Vol. I.

[32] Pedley, J. 2002. Greek Art and Archaeology, Third Edition, London.

[33] Petrie, W. M. Fl. 1886. Naukratis, Part I, 1884-5. London.

[34] Pollitt, J., 1986. Art in Hellenistic Age, Cambridge.

[35] Prinz, H.1908. Funde aus Naukratis,Beitrage zur Archaologie und Wirtschajtsgeschichte des VII.undVI.chr, Leigzig.

[36] Reinach, S., 1889, Les gaulis dans l'arte antique, Paris.

[37] Said, A.2010. Roman Sculpture from the Early Beginnings till the Fourth Century AD, Alexandria.

[38] Shier, L.1906. Terracotta Lamps from Karanis, Michigan.

[39] Stafford, E.2004. Ancient Greece, Life, Myth and Art, London.

[40] Russell, D.2001.The Arts of Prose: The early Empire, in The Roman World, ed. John Boardman, Oxford University Press.

[41] Thomas, R. I. 2011. 'Terracotta figurines'. In Myos Hormos - Quseir al-Qadim. Roman and Islamic ports on the Red Sea 2: Finds from the 1999-2003 excavations, 79-84. D. P. S. Peacock and L. Blue (eds), BAR International Series 2286. Oxford: Archaeopress. 
[42] Thomas, R. I. and Nicholson, P.T. 2013. Figurines. In Working in Memphis: The production of faience at Roman period Kom Helul, 41-74, P. T. Nicholson (ed.). Egypt Exploration Society. London.

[43] Török, L., 1995. Hellenistic and Roman terracottas from Egypt, Roma.

[44] Van De Graaff, K., Fox, S., La Fleur, K., 1997. Synopsis of Human anatomy and physiology, Boston.

[45] Vandorpe, K., 2012. 'Identity in Roman Egypt', in C. Riggs (ed.), The Oxford Handbook of Roman Egypt, Oxford.

[46] Woodford, S., 1982. The Art of Greece and Rome, Cambridge University Press.

\section{AUTHOR'S BIOGRAPHY}

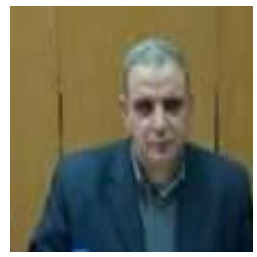

Prof. Dr. Mustafa Muhammad Qandil Zayed, Professor of History of Ancient civilization King Khalid University. Faculty of Humanities; Professor of classical Archaeology, Ain Shams University, Faculty of Arts, Egypt.

Citation: Mustafa Muhammad Qandil Zaied. "Publication and Study of a Rare Terracotta Piece from Naucratis Preserved in the Egyptian Museum in Cairo". International Journal of History and Cultural Studies (IJHCS). vol 5, no. 2, 2019, pp. 30-38. doi: DOI: http://dx.doi.org/ 10.20431/2454-7654.0502003.

Copyright: () 2019 Authors. This is an open-access article distributed under the terms of the Creative Commons Attribution License, which permits unrestricted use, distribution, and reproduction in any medium, provided the original author and source are credited. 